\title{
Evaluation of Corrosion Resistance of Commercial Aluminum Alloys in Ethanol Solutions
}

\author{
Gustavo Raúl Kramer ${ }^{a, c}$, Claudia Marcela Méndez ${ }^{a, c}$, Alicia Esther Ares $^{a, b, c *}$ (i) \\ ${ }^{a}$ Instituto de Materiales de Misiones (IMAM), Consejo Nacional de Investigaciones Cientificas y \\ Técnicas, Universidad Nacional de Misiones (CONICET-UNaM), Félix de Azara 1552, Posadas, \\ Misiones, Argentina \\ ${ }^{b}$ Consejo Nacional de Investigaciones Cientificas y Técnicas, Godoy Cruz, 2290, Buenos Aires, \\ Argentina \\ ${ }^{c}$ Facultad de Ciencias Exactas, Quimicas y Naturales, Universidad Nacional de Misiones, Félix de \\ Azara 1552, Posadas, Misiones, Argentina
}

Received: March 10, 2017; Revised: April 21, 2018; Accepted: September 28, 2018

In the present research, we studied the corrosion resistance of commercial aluminum alloys exposed to ethanol produced in the northeastern region of Argentina and to commercial ethanol as reference medium. Electrochemical tests of potentiodynamic polarization and weight loss were performed by immersion at temperatures below the boiling point of ethanol $\left(25^{\circ} \mathrm{C}, 40^{\circ} \mathrm{C}\right.$ and $\left.50{ }^{\circ} \mathrm{C}\right)$. The results showed that the increase in the corrosion rate of the alloys is directly proportional to the increase in the temperature of the solution, and that the combined action of contaminants in the alcohol (water, organic acids or aggressive ions) contributed to the increase in the aggressiveness of the environment. Specifically, through the results of the gravimetric tests, corrosion products characteristic of the formation of pitting corrosion and alkoxidation were observed. In contrast to the above, the existence of the pitting corrosion mechanism was demonstrated by defining a pitting potential in the potentiodynamic polarization curves.

Keywords: corrosion, aluminum alloys, ethanol.

\section{Introduction}

At present, considering the consequences of the dependence on fossil fuels, their shortage, and the negative effects on the environment caused by the use of petroleum products, it is urgent to direct efforts to solve problems related to the world energy system. Policies implemented in different countries have encouraged initiatives to produce ethanol as an alternative biofuel and a substitute for naphtha, through regulations that allow cushioning the changes in demand and encouraging the gradual growth of biofuel production, thus allowing the adaptation in the markets and applying the replacement of products and technologies ${ }^{1}$. The sustainability of ethanol in Brazil, one of the most important producers and exporters of ethanol in the world, faces challenges ranging from the sociopolitical aspect as well as the economic and environmental impact, concluding the analysis with the formulation of a "Criterion of Sustainability" that promotes the adoption of this bioproduct taking into account the regulatory conditions imposed by the different markets as well as emphasizing the changes necessary for its implementation in the current global economy ${ }^{2}$. Farrell et al. ${ }^{3}$ showed that the production of bioethanol of vegetable origin is economically favorable compared to the gasoline derived from petroleum, because it can generate equal or lesser amounts of greenhouse gases, but requires less quantity of fuels for its production. These

*e-mail: aares@fceqyn.unam.edu.ar authors also suggested that bioethanol of cellulosic origin can generate even less greenhouse gases and uses less quantity of fuels for its production, following the concept of biorefinery. Today, in Argentina, the energy matrix, understood as the percentage of combinations of the sources and technologies used for the consumption of the inhabitants of a place, is almost very dependent on hydrocarbons (35\%on petroleum and $52 \%$ on gas). This makes it essential to consider change towards alternative energies, both because of its positive effects (development of the agricultural sector, regional economic growth, diversification of the country's energy matrix, etc.) and because of the availability of natural resources and developed technology ${ }^{4,5}$.

The main source of ethanol in Argentina is through the fermentation of sugarcane juice, a first generation biofuel. The sugarcane sources of the country extend through the Northwest region, where sugar mills with capacity for production of hydrated and dehydrated ethanol are located, and, to a lesser extent, through the Northeast region. It should be noted that the possibility of achieving the progress of new R \& D projects is currently focused on biotechnology for the development of second and third generation biofuel production methods ${ }^{6}$.On the other hand, the substitution of a product requires the adaptation of existing systems and the evaluation of obsolescence or replacement, either by the behavior of the product (biofuel) or the materials used.

Costa et al. and Cordeiro de Melo et al. ${ }^{7,8}$ have verified a good performance of engines when using hydrated ethanol 
instead of gasoline, as well as a significant increase in the efficiency of the engine and a decrease in the emission of greenhouse gases. An important point to bear in mind when selecting materials for the production, use and transport of these biofuels, is the properties of the material against corrosion. Many studies are carried out exposing metal materials to media that are partly or totally composed of bioethanol. It is assumed that the corrosion of metallic materials in solutions with ethanol is divided into three categories: i)general corrosion, which is attributed to the existence of impurities, aggressive ions and the total acid content (acetic acid), ii) wet or electrochemical corrosion caused by water, which oxidizes most metals, and iii) dry or chemical corrosion, which is due to the structure and polarity of the molecule of ethanol ${ }^{9}$. Ethanol may contain contaminants such as acetic acid, dissolved oxygen, chlorides, sulphates, and metal ions, all of which derive from the ethanol production process, especially from fermentation and distillation. These contaminants can significantly modify the mechanisms of corrosion, depending on the exposure conditions, weather temperature, pressure or concentration of contaminants ${ }^{10-13}$. The conclusions about this vary with respect to the experimental conditions proposed by each author, but indicate that the effects of water and contaminant ions as the main propellants of corrosion for metal/bioethanol systems, and to a lesser extent the effect of the increase of conductivity of the ethanol either by the water content or by the generation of acetic acid by oxidation ${ }^{14-16}$.

Aluminum stands out as a versatile, low-density material with a wide range of applications, with excellent mechanical properties and excellent properties against corrosion, enhanced by the addition of alloys such as silicon, magnesium and copper. Reports from different laboratories and organizations ${ }^{17-19}$ point out those bioethanol producers recommend the use of aluminum. Because most of these studies are focused on the analysis of corrosion under conditions of use at temperatures near the boiling point of ethanol, it is necessary to evaluate the metals exposed to this biofuel at temperatures close to the ambient temperature, achieving a significant approximation to bioethanol production and handling conditions that are not taken into account, such as storage and transport ${ }^{20,21}$.

The objective of this research was to evaluate the corrosion resistance of commercial grade aluminum and AA1050 alloy, when exposed to bioethanol from the province of Misiones, Argentina, and to ethylic reference media (anhydrous ethanol and $96^{\circ}$ ethanol) under simulated working conditions: ambient temperature $\left(25^{\circ} \mathrm{C}\right), 40^{\circ} \mathrm{C}$ and $50{ }^{\circ} \mathrm{C}$ in the presence of oxygen.

\section{Experimental Procedure}

For the tests, anhydrous (absolute) ethanol, commercial96\% ethanol(approx. 4\% water in vol.) and commercial ethanol from San Javier Industry, Misiones, Argentina (SJ ethanol) were used. The characterization of alcohols was carried out based on the quality standards of biofuels, considering the essays of low cost and greater importance ${ }^{22,23}$. The density and the content of ethanol were measured through a glass density meter according to the NBR 5992standard ${ }^{24}$. The total acidity of SJ ethanol was quantified by titration with sodium hydroxide $(\mathrm{NaOH})$, according to the NBR 9866 and ASTM 1613standards ${ }^{25,26}$. Conductivity and $\mathrm{pH}$ were measured through an ADWA AD8000 conductivity meter, adjusted to the NBR 10547 and ASTM D 1125 standards $^{27,28}$.

Chloride ions $\left(\mathrm{Cl}^{-}\right)$were quantified by measuring the turbidity of the medium by adding $0.01 \mathrm{~N}$ silver nitrate $\left(\mathrm{AgNO}_{3}\right)$ in determined quantities and comparing these measurements with a curve calibrated with standards. Table 1 show the characteristics of the different ethanol media evaluated.

The materials tested were commercial grade aluminum (as P0506 pure aluminum) and AA1050 alloy (called A11050 onwards), the composition of which is described in Table 2.

Potentiodynamic measurements in the different media were carried out using a three-electrode electrochemical cell and a Gamry Reference 600 potentiostat, with a potential sweep speed of $0.16 \mathrm{mV} / \mathrm{s}$, between $-0.3 \mathrm{~V}$ and $+1 \mathrm{~V}$, with respect to the Open Circuit Potential, at ambient temperature $\left(25^{\circ} \mathrm{C}\right), 40^{\circ} \mathrm{C}$ and $50^{\circ} \mathrm{C}$, using a reference electrode of $\mathrm{Ag} /$ $\mathrm{AgCl} / \mathrm{KCl}$ (sat). The corresponding electrochemical parameters were then obtained through the application of the Tafel extrapolation. Considering that the polarization resistance ( $R_{p}$, with unit of $\mathrm{k} \Omega \cdot \mathrm{cm}^{2}$ ) is defined as the slop (tangent) of the potential vs. current density curve at Corrosion Potential ( $E_{\text {corr }}$, in V)according to equation $(1)^{29}$, it was calculated through the method of the least squares using the potential and current points close to the corrosion potential.

$$
R_{p}=\left(\frac{d E}{d i}\right)_{E_{\text {corr }}}
$$

In the same way, the Stern-Gray equation ${ }^{29}(2)$ was applied to obtain the corrosion current density $\left(i_{\text {corr }}\right.$, in $\left.\mu \mathrm{A} \cdot \mathrm{cm}^{-2}\right)$, correspondingly fitting the anodic $\left(\beta_{\mathrm{a}}\right.$, in $\left.\mathrm{V}\right)$ and cathodic $\left(\beta_{\mathrm{c}}\right.$, in $\left.\mathrm{V}\right)$ Tafel slopes,

$$
i_{\text {corr }}=\frac{\beta_{a} * \beta_{c}}{2.03 *\left(\beta_{a}+\beta_{c}\right)} * \frac{1}{R_{p}}
$$

And the equation deduced from Faraday's Law (3) ${ }^{29}$ was used to calculate the corrosion rate $\left(\mathrm{V}_{\text {corr }}\right.$, in mm.year-1 $\left.{ }^{-1}\right)$,

$$
V_{\text {corr }}=k * \frac{i_{\text {corr }}}{\rho} * E W
$$

Where $k$ is a conversion constant $\left(3.27 * 10^{-3} \mathrm{~mm} \cdot \mathrm{g} \cdot \mu \mathrm{A}^{-1}\right.$. $\mathrm{cm}^{-1}$.year $\left.{ }^{-1}\right), \rho$ is the density of the alloy in $\mathrm{g} . \mathrm{cm}^{-3}$ and $E W$ is the equivalent weight of the alloy (in this equation is considered dimensionless).

The ohmic drops produced by the low conductivity of the medium were taken into account and corrected without the addition of mediumelectrolytes ${ }^{30}$, from the measurement of 
Table 1. Characteristics of the three ethanolic solutions evaluated.

\begin{tabular}{|c|c|c|c|c|c|c|c|c|}
\hline Solutions & $\begin{array}{c}\text { Density at } \\
2^{\circ} \mathrm{C}\left(\mathrm{kg} \cdot \mathrm{m}^{-3}\right)\end{array}$ & Alcoholicgrade & $\begin{array}{l}\text { Appearance } \\
\text { and color }\end{array}$ & $\begin{array}{c}\text { Total acidity } \\
\text { (wt.\%) }\end{array}$ & $\begin{array}{c}\text { Conductivity } \\
\left(\mu{\left.\mathrm{S} . \mathrm{cm}^{-1}\right)}\right.\end{array}$ & pH & \multicolumn{2}{|c|}{$\begin{array}{l}\text { Chloride content } \\
\text { (ppm) }\end{array}$} \\
\hline $\begin{array}{l}\text { Anhydrous } \\
\text { Ethanol }\end{array}$ & 796.5 & 99.5 & & $\begin{array}{l}\text { Clean and } \\
\text { free of } \\
\text { impurities }\end{array}$ & $<0.003$ & $<1.6$ & - & $<1.10$ \\
\hline $\begin{array}{l}\text { Ethanol } \\
96 \%\end{array}$ & 810 & 96 & & $\begin{array}{l}\text { Colorless. } \\
\text { Clean and } \\
\text { free of } \\
\text { impurities }\end{array}$ & $<0.003$ & $<3$ & 6.5 & $<1.10$ \\
\hline $\begin{array}{l}\text { S J } \\
\text { Ethanol }\end{array}$ & 812 & 92 & & $\begin{array}{l}\text { Colorless. } \\
\text { Clean } \\
\text { with some } \\
\text { impurities }\end{array}$ & $0.00169 \pm 0.00045$ & $4.7 \pm 0.3$ & 6.5 & 4.95 \\
\hline
\end{tabular}

Table 2. Composition of the aluminum alloys evaluated.

\begin{tabular}{llccccccccc}
\hline Alloy & $\mathbf{w t} \%$ & $\mathbf{S i}$ & $\mathbf{F e}$ & $\mathbf{C u}$ & $\mathbf{M n}$ & $\mathbf{M g}$ & $\mathbf{Z n}$ & $\mathbf{T i}$ & others & Al \\
\hline $\begin{array}{l}\text { Commercial } \\
\text { aluminum }\end{array}$ & Min. & - & - & - & - & - & - & - & - & - \\
\multirow{2}{*}{ Al1050 } & Max. & 0.05 & 0.06 & - & - & - & 0.01 & - & 0.08 & Rem. \\
& Min. & - & - & - & - & - & - & - & - & - \\
& Max. & 0.25 & 0.4 & 0.05 & 0.05 & 0.05 & 0.07 & 0.05 & 0.03 & Rem. \\
\hline
\end{tabular}

the resistivity of the medium prior to each test $\left(R_{\text {average }}\right.$, in Ohm $\mathrm{cm}^{2}$ ), considering the spatial arrangement of the electrodes in the cell and determining each potential by equation (4):

$$
E_{\text {corrected }}=E_{\text {measured }}+i R_{\text {average }}
$$

Where $E_{\text {measured }}$ and $I$ are correspondingly the potential (in $\mathrm{V}$ ) and the current density (in $\mu \mathrm{A} . \mathrm{cm}^{-2}$ ) measured in the potentiostat, and $E_{\text {corrected }}$ is the potential corrected(in $\mathrm{V})$ by the application of the previous formula. This allows compensating the ohmic drop generated by ethanol at each potential point measured.

The weight loss tests were carried out according to ASTM G31 standard ${ }^{31}$, with specimens being constructed of materials with a thickness of $1 \mathrm{~mm}$ and a width/length ratio of approximately $1 / 2$, and also with a perforation in the upper zone to achieve the suspension with nylon threads within the corrosive medium (Figure 1 a). Said specimens were immersed in $\mathrm{SJ}$ ethanol in specially prepared containers (Figure 1.b), for a period of 16 days at $25^{\circ} \mathrm{C}, 40^{\circ} \mathrm{C}$ and at $50^{\circ} \mathrm{C}$, at a volume/area ratio of the specimen of $0.2 \mathrm{~mL} \cdot \mathrm{mm}^{-2}$ (see Figure 1). The evaporation of the medium was periodically monitored, and if a decrease of $1 \%$ of the original volume was identified, it would proceed to the addition of alcoholic solution, as specified by the ASTM G31 standard ${ }^{31}$. After this immersion time, the specimens were removed from the containers for visual analysis, and then washed in an ultrasonic bath and air-dried.

After the weight loss essays, the specimens were analyzed through a metallurgical microscope, Scanning
Electron Microscopy (SEM) and Energy-Dispersive X-Ray Spectroscopy (EDX).

\section{Results and Discussion}

\subsection{Potentiodynamic polarization}

By analyzing the curves for commercial grade aluminum immersed in anhydrous ethanol and 96\% ethanol at the three temperatures evaluated (Figure 2 and 3 respectively), it can be seen that they are similar in shape. In both cases, they show a gradual dissolution of the metal, with an elevated slope of the anodic branch (in comparison with those obtained in aqueous media), a behavior that is characteristic of alcoholic media $^{16,32-34}$. It is notable that the addition of water to the alcoholic medium ( $4 \%$ by volume) significantly increases the slopes of the anodic branches of the curves of the material in the three temperatures, but on the other hand an increase in the values of the $E_{\text {corr }}$ is observed, that agrees with Totten and MacKenzie ${ }^{35}$. Table 3 shows that, for these two media (anhydrous ethanol and $96 \%$ ethanol), the $E_{\text {corr }}$ was higher at $40^{\circ} \mathrm{C}$ than at $50^{\circ} \mathrm{C}$, possibly due to the change in structure of the oxide layer formed on the surface of the metal ${ }^{36}$.However, the $i_{\text {corr }}$ described an increase as the temperature increased, correspondingly decreasing the $R_{p}$, possibly due to the temperature activation of the electrochemical reactions ${ }^{37,38}$.

When the metal was exposed to SJ ethanol, the curves changed their shape drastically (Figure4), describing a characteristic electrochemical behavior of aqueous alloys subjected to aqueous solutions with aggressive ions dissolved therein, identifying a very small pseudopassivation zone, 


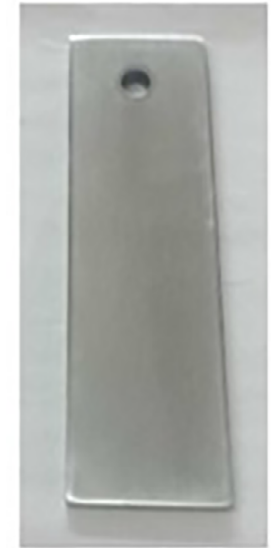

Al 1050

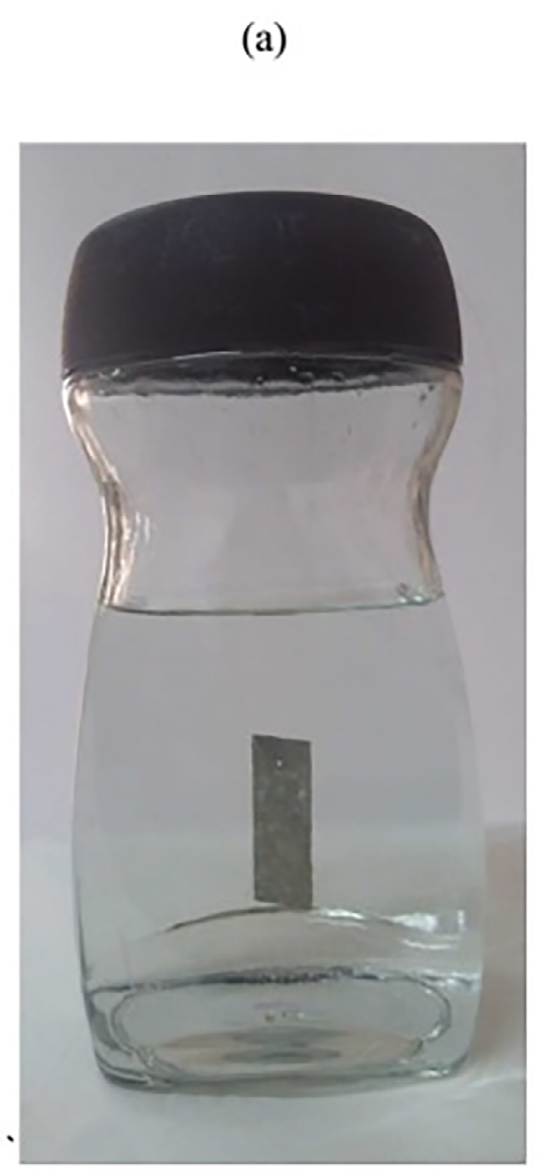

(b)

Figure 1. (a) Test pieces for weight loss assays. (b) Container for testing of weight loss and disposition of the test pieces.

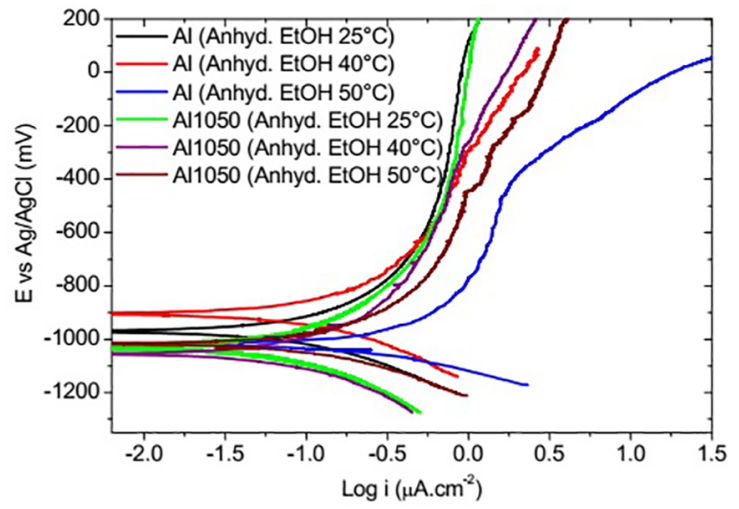

Figure 2. Potentiodynamic polarization curves for commercial grade aluminum (Al) and Al 1050 alloy in anhydrous ethanol at $25^{\circ} \mathrm{C}, 40^{\circ} \mathrm{C}$ and $50^{\circ} \mathrm{C}$.

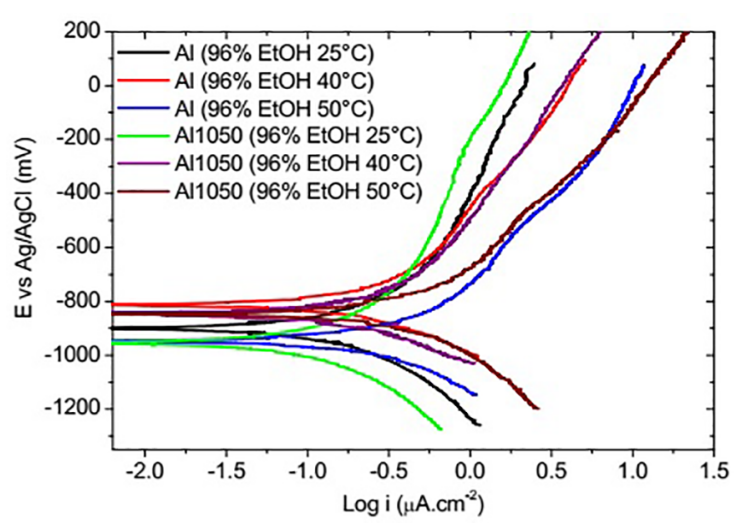

Figure 3. Potentiodynamic polarization curves for commercial grade aluminum $(\mathrm{Al})$ and $\mathrm{Al} 1050$ alloy in $96 \%$ ethanol at $25^{\circ} \mathrm{C}$, $40^{\circ} \mathrm{C}$ and $50^{\circ} \mathrm{C}$.

followed by the tripping of the current defining a pitting potential. This may be the effect of the joint action of different corrosion mechanisms, that is, the presence of water and contaminants, such as organic acids and aggressive ions dissolved in the medium. In addition to the dissolution by reaction with water and by the formation of alkoxides ${ }^{39}$, is added the phenomenon of formation of a resistive layer of products on the metal surface and subsequent embrittlement thereof, and localized attack on the material $1^{10,13}$.

The values of $i_{\text {corr }}$ increased significantly and in function with the increase in temperature. Consequently, the $R$ value decreased (Table 3).

The results obtained from the potentiodynamic polarization tests for the Al 1050 alloy (in the different media and at the different temperatures evaluated) are also shown in Figure 2, 3 and 4,and the corresponding Tafel extrapolation results are shown in the Table 4. By analyzing these data, differences are observed between the curves and the values of the electrochemical parameters with respect to the commercial grade aluminum. These differences are denoted in the potentiodynamic curves of the Al 1050 alloy immersed in anhydrous ethanol, where the value of 
Table 3. Electrochemical parameters obtained through extrapolation of Tafel for commercial grade aluminum.

\begin{tabular}{|c|c|c|c|c|c|c|}
\hline Alloy & Ethanol & Temp. $\left({ }^{\circ} \mathrm{C}\right)$ & $\mathrm{E}_{\text {corr }}(\mathrm{mV})$ & $\mathbf{R}_{p}\left(k \Omega \cdot \mathbf{c m}^{2}\right)$ & $i_{\text {corr }}\left(\mu \mathrm{A} \cdot \mathrm{cm}^{-2}\right)$ & $\begin{array}{c}\mathbf{V}_{\text {corr }}(\mathbf{m m} \\
\left.\text { year-1 }^{-1}\right)\end{array}$ \\
\hline \multirow{9}{*}{$\begin{array}{l}\text { Commercial } \\
\text { Aluminum }\end{array}$} & \multirow{3}{*}{ S J } & 25 & -934.00 & 120.671 & 0.180 & 0.0020 \\
\hline & & 40 & -963.00 & 73.472 & 0.322 & 0.0035 \\
\hline & & 50 & -991.00 & 53.068 & 0.372 & 0.0041 \\
\hline & \multirow{3}{*}{$96 \%$} & 25 & -899.83 & 378.617 & 0.057 & 0.0006 \\
\hline & & 40 & -813.26 & 242.372 & 0.090 & 0.0010 \\
\hline & & 50 & -946.34 & 202.983 & 0.107 & 0.0012 \\
\hline & \multirow{3}{*}{ Anhydrous } & 25 & -970.05 & 532.879 & 0.041 & 0.0004 \\
\hline & & 40 & -904.21 & 451.840 & 0.048 & 0.0005 \\
\hline & & 50 & -1017.46 & 152.879 & 0.142 & 0.0015 \\
\hline
\end{tabular}

$E_{\text {corr }}$ remained constant even as the temperature increased, and the increase in $i_{\text {corr }}$ was less abrupt than in the case of commercial grade aluminum (Figure 2 and Table 4).In the case of $96 \%$ ethanol, the water content of the medium increased the values of the $E_{\text {corr }}$ as the temperature increased, but on the other hand, the $i_{\text {corr }}$ increased in comparison with the case of anhydrous alcohol, possibly due to the corrosion mechanisms activated by the temperature ${ }^{37,38}$, by the water content, and also by the formation of oxides of the alloying materials that are incompatible with the oxides of the matrix material, promoting the dissolution of the material ${ }^{40,41}$.

The behavior of the Al 1050 alloy in SJ ethanol was slightly better than that of commercial grade aluminum, except that the value of $E_{\text {corr }}$ decreases significantly when the temperature reaches $40^{\circ} \mathrm{C}$ and then increases, and also that the $R_{p}$ decreased more significantly from $40^{\circ} \mathrm{C}$ to $50^{\circ} \mathrm{C}$ in this media, increasing in the same way the $i_{\text {corr }}$ and correspondingly the $V_{\text {corr }}$. Likewise, the results show that the A11050 alloy demonstrates greater stability in the medium at $40^{\circ} \mathrm{C}$ compared to commercial grade aluminum, but they are similar in performance at $50^{\circ} \mathrm{C}$. Even so, the values of $R_{p}$ of the Al1050 alloy in SJ ethanol were lower than those obtained in the other media (anhydrous ethanol and 96\% ethanol), showing once again the joint action of aggressive ions, aqueous solution and alkoxidation as mechanisms of corrosion.

\subsection{Gravimetry}

After 16 days of immersion in SJ ethanol at three temperatures $\left(25^{\circ} \mathrm{C}, 40^{\circ} \mathrm{C}\right.$ and $\left.50^{\circ} \mathrm{C}\right)$, the specimens showed corrosion products, especially in the form of pitting (Figure 5). According to Parket al., the presence of ethanol can dehydrate the passive film formed on the alloys and thus promote the formation of cracks in the oxide layer ${ }^{37}$. In the presence of water, organic acids and aggressive ions in the medium promote the formation of corrosion by pitting, in agreement with the results obtained in the weight loss tests.

Figure 6 shows the mass losses of aluminum alloys in ethanol SJ at different temperatures after 16 days of immersion.

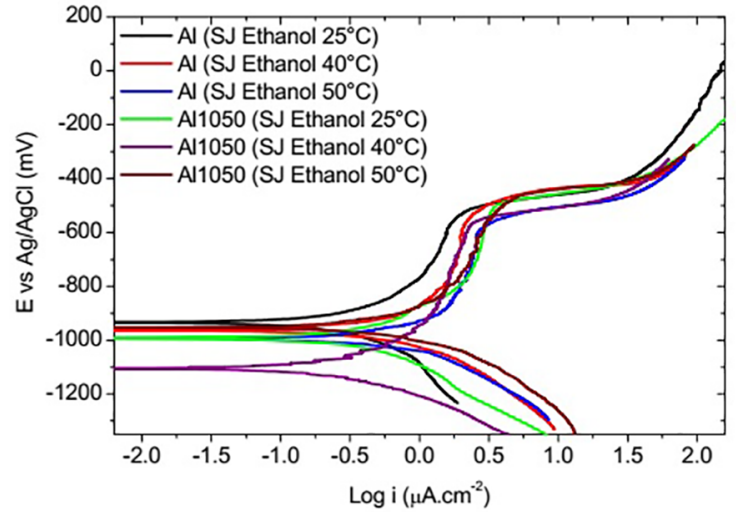

Figure 4. Potentiodynamic polarization curves for commercial grade aluminum (Al) and Al 1050 alloy in SJ ethanol at $25^{\circ} \mathrm{C}$, $40^{\circ} \mathrm{C}$ and $50^{\circ} \mathrm{C}$.

The values of mass loss obtained are significantly lower than those proposed by Parket al., at higher temperatures (above $60^{\circ} \mathrm{C}$ ) for other aluminum-based alloys, which exceed $0.5 \mathrm{mg} . \mathrm{cm}^{-2}$ loss of material ${ }^{37}$.

The loss of mass for the commercial grade aluminum is directly proportional to the increase in temperature, maintaining constant the slope of the curve. For the Al1050 alloy, the increase in temperature to $40^{\circ} \mathrm{C}$ has a slope similar to that obtained for the aluminum of commercial purity, but when increasing the temperature from $40^{\circ} \mathrm{C}$ to $50^{\circ} \mathrm{C}$, a decrease in the slope is noted. This being produced by the effect of the alloying agents, that is by the formation of thermally stable corrosion products that achieve the inhibition of the dissolution of the material in the medium ${ }^{35,40}$ (Figure 6).

According to the analysis of EDX carried out in the areas adjacent to the pits (Figure 7), and in agreement with Park et $\mathrm{al}^{37}$, the formation of a homogeneous layer of hydrated aluminum oxide surrounding the pit was identified, and which dehydrates and cracks when it approaches to the pit, forming a front of dehydrated oxide that exposes the matrix material. According to Pourbaix ${ }^{42}$, aluminum exposed to an aqueous medium containing aggressive ions $\left(\mathrm{Cl}^{-}\right.$in this case) can form hydrated and dehydrated aluminum oxides, in addition to 
Table 4. Electrochemical parameters obtained through extrapolation of Tafel for alloy Al 1050.

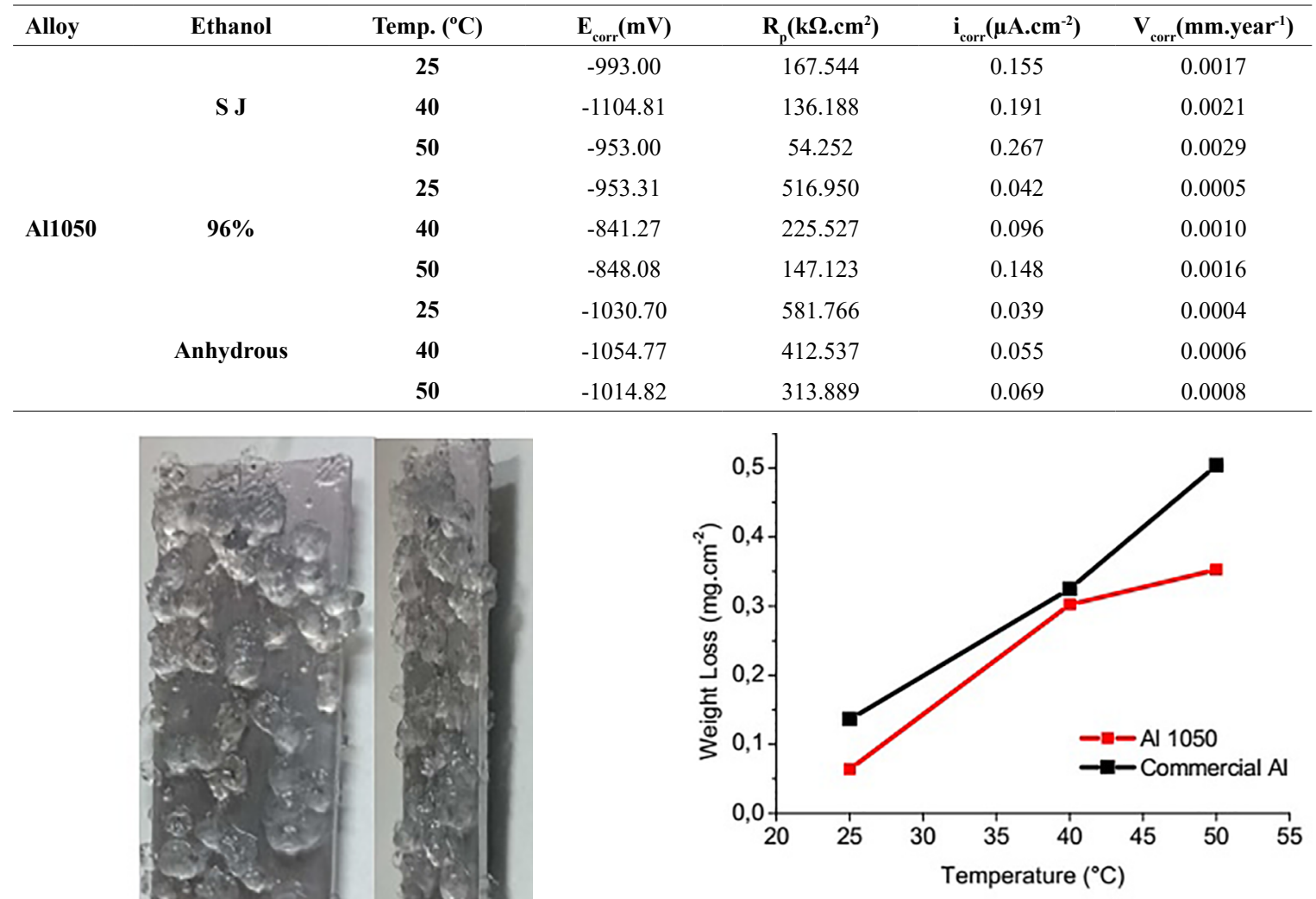

Figure 6. Weight loss of aluminum alloys after 16 days of immersion in $\mathrm{SJ}$ ethanol at different temperatures.

characteristic corrosion products such as aluminum hydroxide (proper of the result of a pitting corrosion mechanism).he results of EDX showed the presence of carbon (C), which could indicate the presence of compounds such as aluminum alkoxide $\left(\mathrm{Al}\left(\mathrm{C}_{2} \mathrm{H}_{5} \mathrm{O}\right)_{3}\right)$, allegedly as a product of alkoxidation, according to possible reactions for aluminum exposure in ethanol $^{21,43}$, and furthermore, signs of the presence of chlorine were identified through the same technique, possibly due to the existence of chlorinated compounds adsorbed on the metal surface.

\subsection{Pitting corrosion analysis}

When the formation of pitting was observed, because of the exposure of metals to SJ ethanol, the ASTM G46 standard was applied ${ }^{44}$. This standard states that when this type of corrosion is detected on the test specimens tested for weight loss, the phenomenon must be described according to the characteristics of the pitting in the test pieces.

In this way, the density of the bites on the surfaces of the samples was quantified and the depths thereof were measured taking into account their morphologies below the surface.

The pitting density is defined as the number of pit units formed per $\mathrm{cm}^{2}$ of test piece surface. The results of this analysis are shown in Table 5, where the alloys immersed in $\mathrm{SJ}$ ethanol for 16 days at different temperatures are compared.

re 5. (a) Commercial aluminum in ethanol $\mathrm{SJ}$ a $40^{\circ} \mathrm{C}$ after 16 days of immersion. (b) $\mathrm{Al}$ 1050 in $\mathrm{SJ}$ ethanol at $50^{\circ} \mathrm{C}$ after 16 days of immersion. 
Commercial grade aluminum alloy exposed in $\mathrm{SJ}$ ethanol at $25^{\circ} \mathrm{C}$ for 16 days.
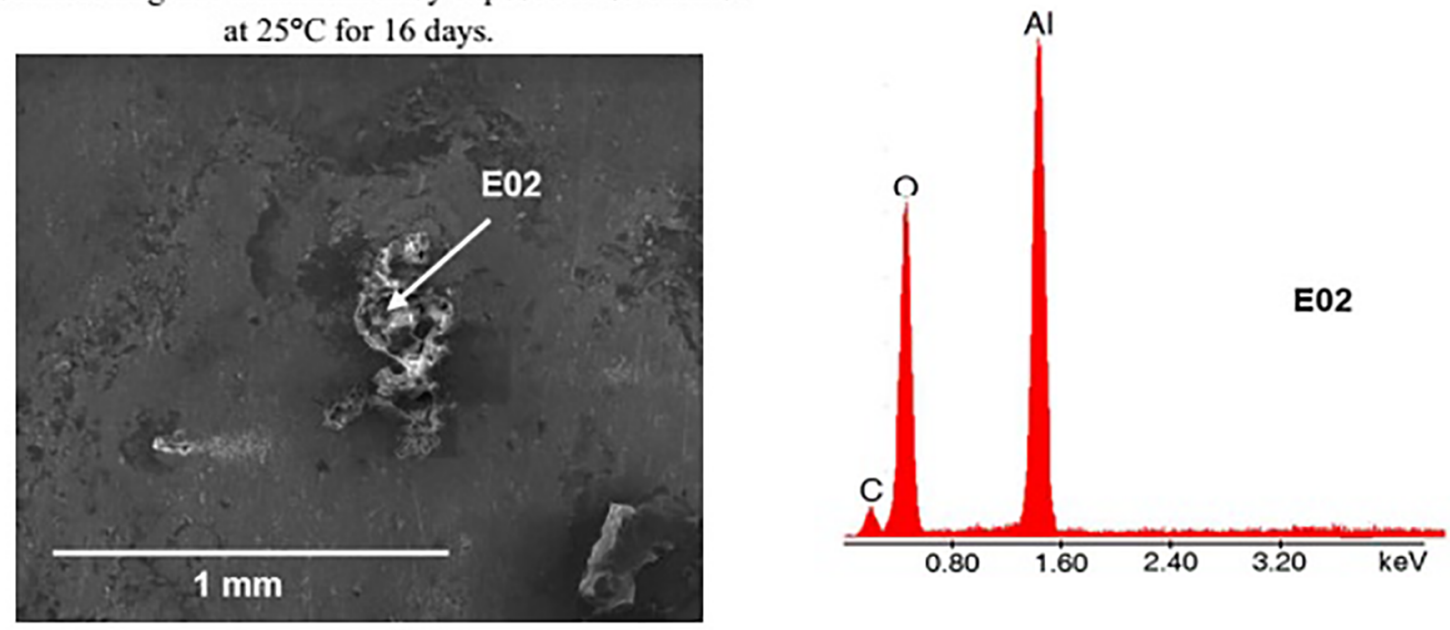

Commercial grade aluminum alloy exposed in $\mathrm{SJ}$ ethanol at $40^{\circ} \mathrm{C}$ for 16 days.
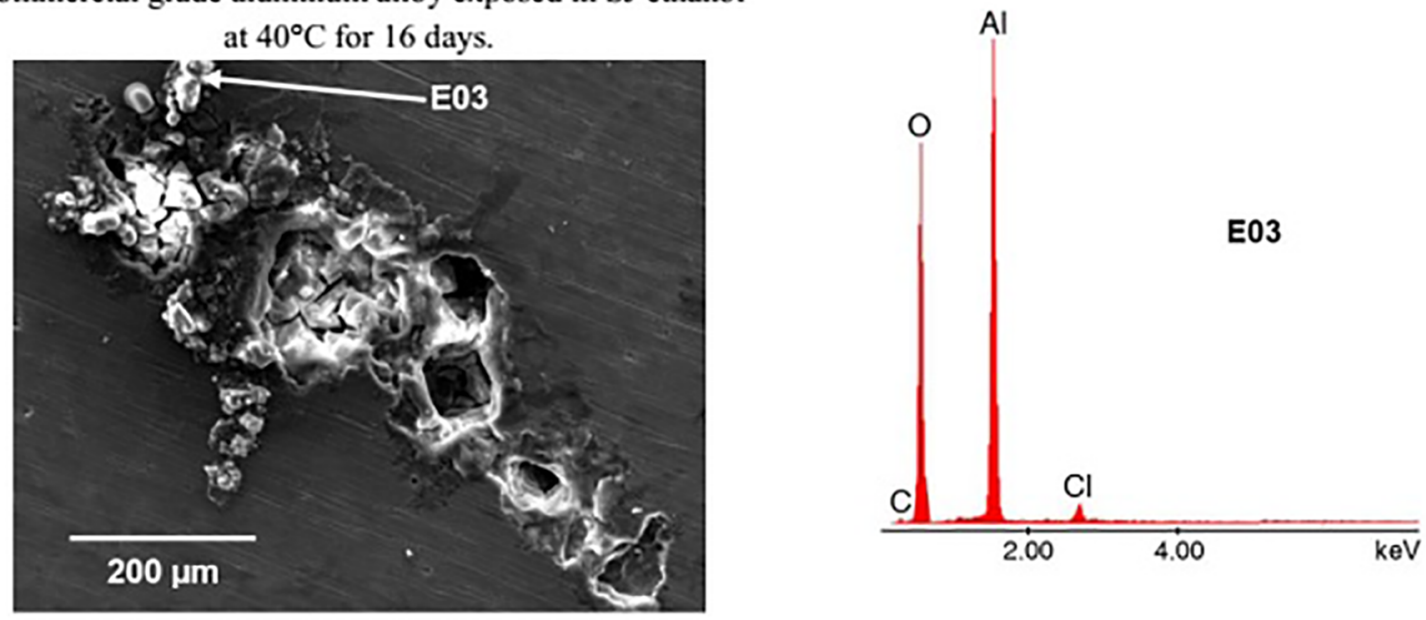

Al1050 alloy exposed in SJ ethanol at $40^{\circ} \mathrm{C}$ for 16 days.
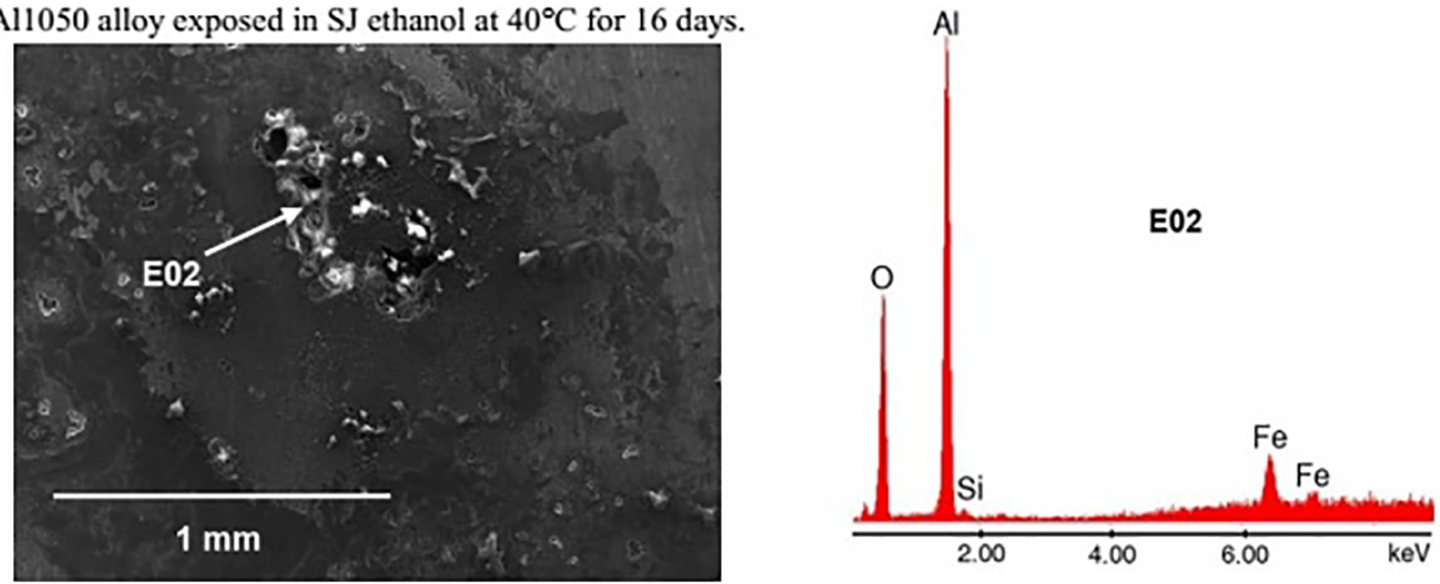

Figure 7. SEM and EDX at different points on the surfaces of the materials after the gravimetric tests.

These results show that, for the case of the commercial grade aluminum, the pitting density increased slightly as the temperature increased, whereas for the $\mathrm{Al} 1050$ alloy, the pitting density increased only until $40^{\circ} \mathrm{C}$, and then decreased when reaching $50^{\circ} \mathrm{C}$. The latter is possibly due to interference between mechanisms of corrosion, to form 
corrosion products that are more stable at higher temperatures and less soluble in the organic medium, thus inhibiting the corrosion by pitting in this case.

The penetration of the metal by corrosion can be expressed by the depth of pitting, or the average depth, and by the pitting factor, which is given according to the equation(5):

$$
\text { Pitting Factor }=\frac{\text { Greater depth of pitting }}{\text { Average pitting }}
$$

Because the pits can have various sizes and shapes, a cross section of the pits was made to see its real shape and determine its true depth (Figure 8).

The depth of the pits was determined with the method proposed by the ASTM G46 standard ${ }^{44}$ and using a metallurgical microscope. The results obtained are shown in Table 6 .

The values of the depths and of the pitting factors have direct incidence on the mechanical properties of the material, taking into account the application and theconditions to which this material will be subjected, being of special interest when forming a container containing fluids. This is the case of materials that are intendedfor the construction of equipment for the handling of ethanol.

The results in Table 6 show that, according to the pitting factor, in all cases, the values obtained were greater than unity, thus confirming the corrosion in the form of pitting and not a corrosion in general form (pitting factor equal to the unit). On the other hand, the average pitting depths for both alloys increased proportionally with the temperature increase, but in no case exceeded $0.2 \mathrm{~mm}(200 \mu \mathrm{m})$, which relatively represents a low depth value (according to ASTM G46 standard ${ }^{44}$ ).Even so, the rigor of this type of attack on the material is completely defined, subjecting it to the efforts of the working conditions. According to Song and $\mathrm{Liu}^{21}$, by exposing a metallic material in a medium composed of ethyl alcohol plus water (from $4 \%$ to $8 \% \mathrm{w} / \mathrm{w}$ water) and considering the existence of contaminants such as organic acids (acetic acid) and aggressive ions $\left(\mathrm{Cl}^{-}\right)$, the possible anodic and cathodic reactions would be:

Anodic reactions (equation (6) and (7)):

$$
\begin{gathered}
A l_{(s)} \rightarrow A l_{(\text {dissolved })}^{+3}+3 e \\
A l_{(s)}+C l_{(\text {dissolved })}^{-} \rightarrow A l C l_{3(s)}+3 e
\end{gathered}
$$

According to Seri and $\mathrm{Kido}^{45}$ due to the presence of chloride ions dissolved in the medium.

Cathodic reactions (equation (8) to (10)):

$3 \mathrm{CH}_{3} \mathrm{CH}_{2} \mathrm{OH}_{(l)}+3 e \rightarrow 3 \mathrm{CH}_{3} \mathrm{CH}_{2} \mathrm{O}_{(\text {dissolved })}^{-}+\frac{3}{2} \mathrm{H}_{2(g)}$

$2 \mathrm{H}_{2} \mathrm{O}_{(l)}+2 e=2 \mathrm{OH}^{-}+2 \mathrm{H}^{+}+2 e \rightarrow$

$2 \mathrm{OH}_{(\text {dissolved })}^{-}+\mathrm{H}_{2(g)}$
Table 5. Pitting density for alloys at different temperatures after 16 days of immersion in SJ ethanol, in pits per $\mathrm{cm}^{2}$ (average $\pm \sigma$ ).

\begin{tabular}{lccc}
\hline \multirow{2}{*}{ Alloy } & \multicolumn{3}{c}{ Temperature $\left({ }^{\circ} \mathbf{C}\right)$} \\
& $\mathbf{2 5}$ & $\mathbf{4 0}$ & $\mathbf{5 0}$ \\
\hline Commercial aluminum & $10 \pm 3.8$ & $15 \pm 2.2$ & $16 \pm 3.6$ \\
Al1050 & $10 \pm 4.7$ & $17 \pm 3.1$ & $3 \pm 1$ \\
\hline
\end{tabular}

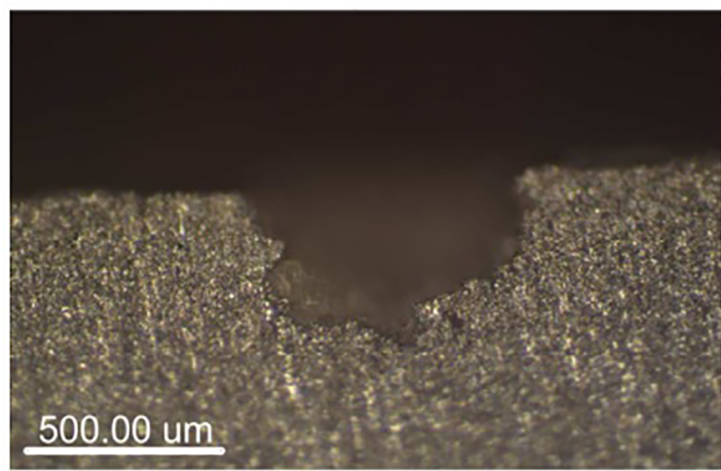

Figure 8. Pit morphology of the Al 1050 alloy specimen: Crosssectional view of the pit.

$$
\begin{aligned}
& 2 \mathrm{CH}_{3} \mathrm{CHOOH}_{(\mathrm{l})}+2 e=2 \mathrm{CH}_{3} \mathrm{COO}_{(\text {dissolved })}^{-}+ \\
& 2 \mathrm{H}^{+}+2 e \rightarrow 2 \mathrm{CH}_{3} \mathrm{COO}_{(\text {dissolved })}+2 \mathrm{H}_{2(\mathrm{~g})}
\end{aligned}
$$

The potentiodynamic tests of the alloys in SJ ethanol showed the existence of a pseudopassivation zone, which suggests the formation of a resistive layer. If the formation reaction of this layer were due to the existence of water only in the medium, such phenomenon would be corroborated in the polarization curves in $96 \%$ ethanol. Since this is not the case, the results may indicate the adsorption of corrosion products (according to previous reactions) on the material. Some of these corrosion products were identified qualitatively by EDX analysis, which would be hydroxides, oxides, as well as carbon compounds, such as alkoxides (insoluble in ethanol) and acetates (water soluble). The reduction of the corrosion resistance of the alloys in SJ ethanol when the temperature varies would be directly related both to the structure of the oxide layer of the material ${ }^{35}$ and to the stability of these corrosion products on the layer.

Forged alloys of the 1XXX commercial series have high corrosion resistance in different media, but this quality decreases with the increasing amount of alloying elements in the matrix ${ }^{46}$. Table 2 shows that the most abundant alloys are iron and silicon. Part of the silicon may be present in solid solution, while the iron along with the silicon may form part of the secondary phases (present in the form of $\mathrm{Al}_{3} \mathrm{Fe}$ and $\mathrm{Al}_{12} \mathrm{Fe}_{3} \mathrm{Si}$ ), which have nobler potentials than aluminum (i.e., more cathodic than aluminum) $)^{40,46}$, which was corroborated with the signals in the EDX analyzes close to the pits (Figures 6), and also by means of an EDX 
Table 6. Depth of pits for alloys at different temperatures after 16 days of immersion in S J ethanol.

\begin{tabular}{lccccccccc}
\hline Alloy & \multicolumn{1}{c}{ Temperature } \\
\cline { 2 - 10 } & $\begin{array}{c}\text { Maximum } \\
\text { pit } \\
\text { depth }(\boldsymbol{\mu m})\end{array}$ & $\begin{array}{c}\text { Average } \\
\text { Pit depth } \\
(\boldsymbol{\mu m})\end{array}$ & $\begin{array}{c}\text { Pitting } \\
\text { factor }\end{array}$ & $\begin{array}{c}\text { Maximum } \\
\text { pit } \\
\text { depth }(\boldsymbol{\mu m})\end{array}$ & $\begin{array}{c}\text { Average } \\
\text { Pit depth } \\
(\boldsymbol{\mu m})\end{array}$ & $\begin{array}{c}\text { Pitting } \\
\text { factor }\end{array}$ & $\begin{array}{c}\text { Maximum } \\
\text { pit } \\
\text { depth( }(\mu \mathrm{m})\end{array}$ & $\begin{array}{c}\text { Average } \\
\text { Pit depth } \\
(\boldsymbol{\mu m})\end{array}$ & $\begin{array}{c}\text { Pitting } \\
\text { factor }\end{array}$ \\
\hline $\begin{array}{l}\text { Commercial } \\
\text { aluminum }\end{array}$ & 135 & 85.85 & 1.57 & 190 & 112 & 1.7 & 170 & 127 & 1.33 \\
Al1050 & 180 & 114 & 1.57 & 165 & 111 & 1.48 & 190 & 157 & 1.21 \\
\hline
\end{tabular}

mapping analysis on the metal samples before the corrosion tests (see Figures 9 and 10).

In addition, when secondary phase particles are present on the surface, passive layers may not form on them or they can modify the layer composition on areas surrounding the particle, then localized stacks or aggressive ion deposition may occur.

The phenomena described above reinforce the assumption that the predominant mechanism by which the materials studied dissolves is by pitting corrosion. The pitting corrosion must be developed in a medium with sufficient conductivity so that it can allow the movement of charged species, and in this case, the presence of water in ethanol ensures this condition. Another condition necessary for the occurrence of pitting corrosion is the existence of an aggressive ion, in this case the ion $\mathrm{Cl}^{-}$, whose quantities are indicated in Table 1 .

The supposed and proposed reactions and mechanisms are outlined in Figure 11.

The aluminum hydroxide $\left(\mathrm{Al}(\mathrm{OH})_{3}\right)$ compound deposited in the vicinity of the pitting can be observed in the samples obtained by immersion (Figure 4). This compound has low solubility in aqueous solution and in ethanol.

Briefly, the analysis by comparing the bibliographies used and the results obtained converge to the explanation of a more complex corrosion phenomenon, which is manifested
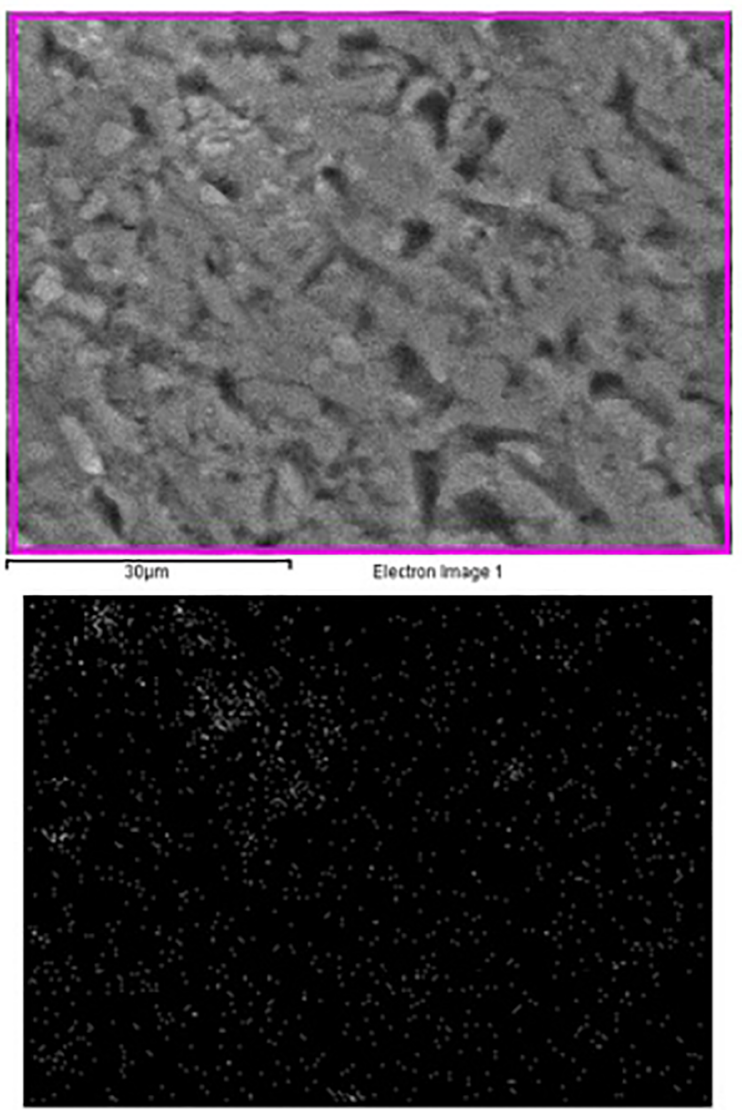

Fe Ka1

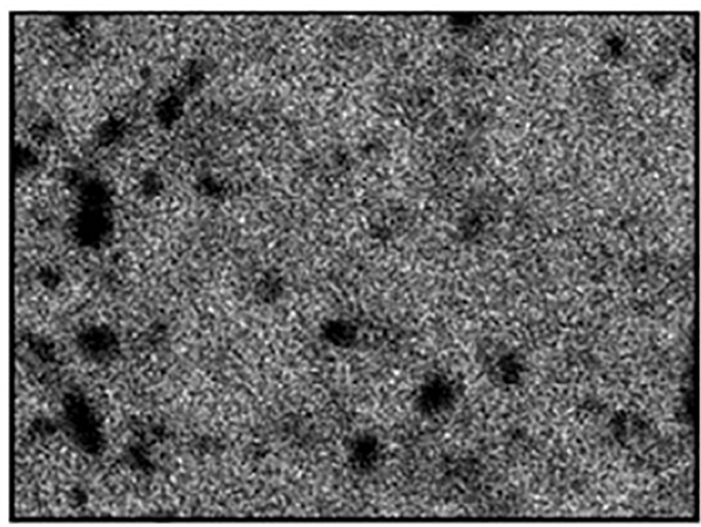

Al Ka1

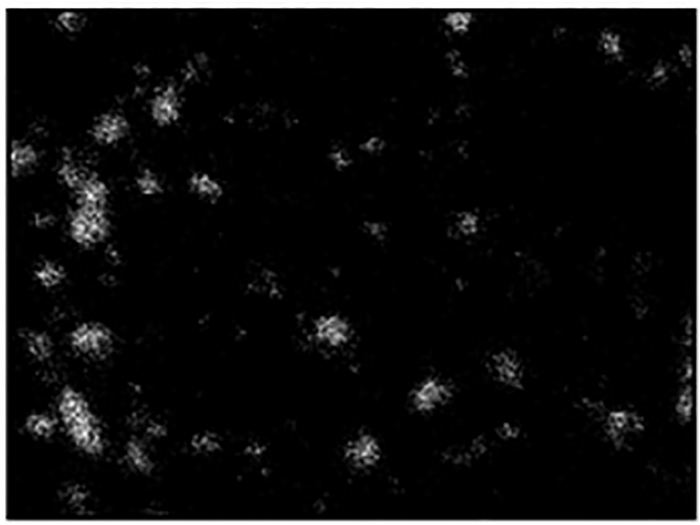

Si Ka1

Figure 9. SEM and EDX mapping on commercial aluminum alloy before corrosion tests. The brightness indicates the intensity of the signal of the corresponding element. 

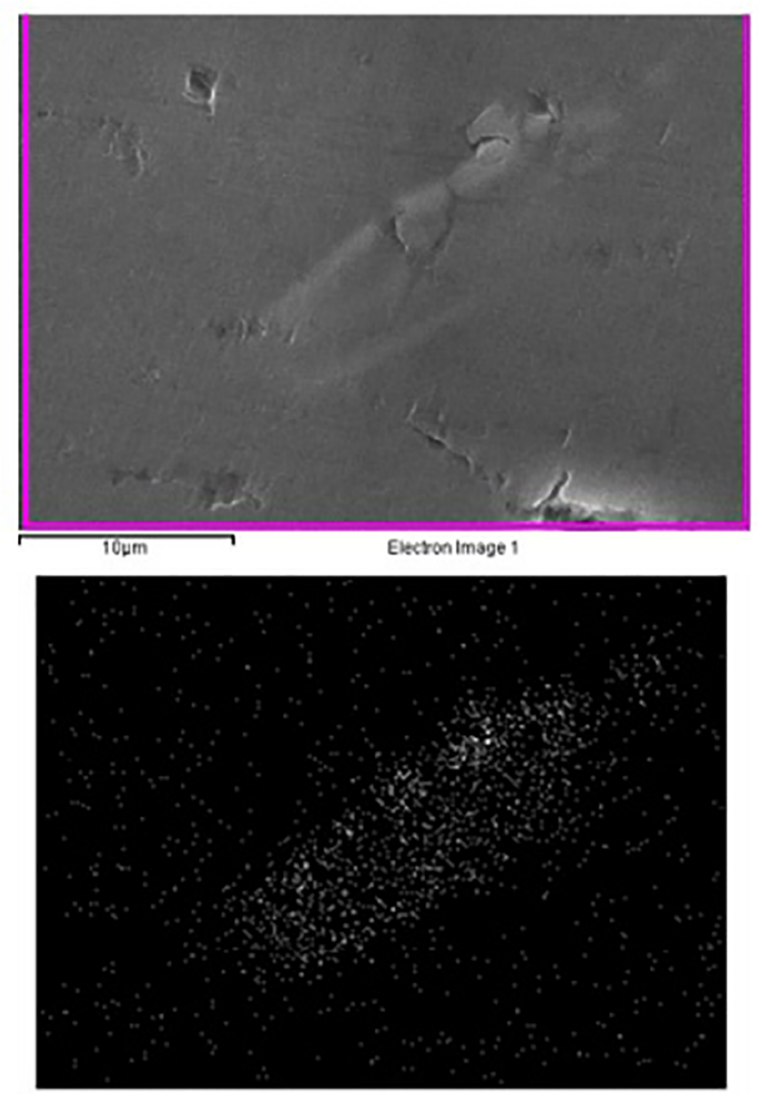

Fe Ka1

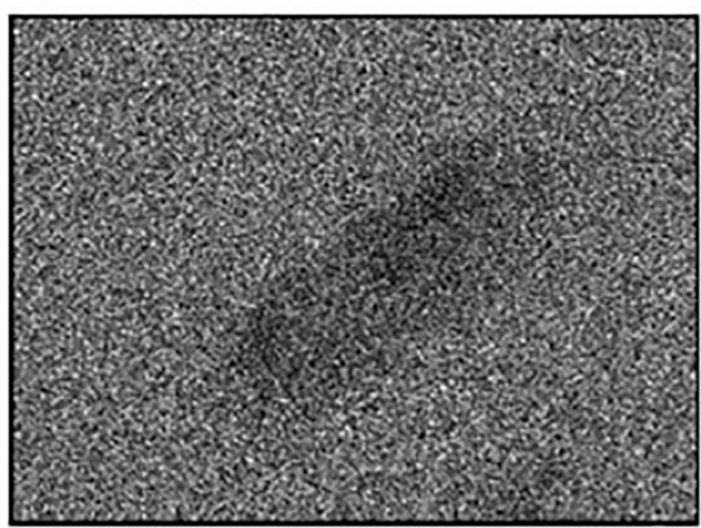

\section{Al Ka1}

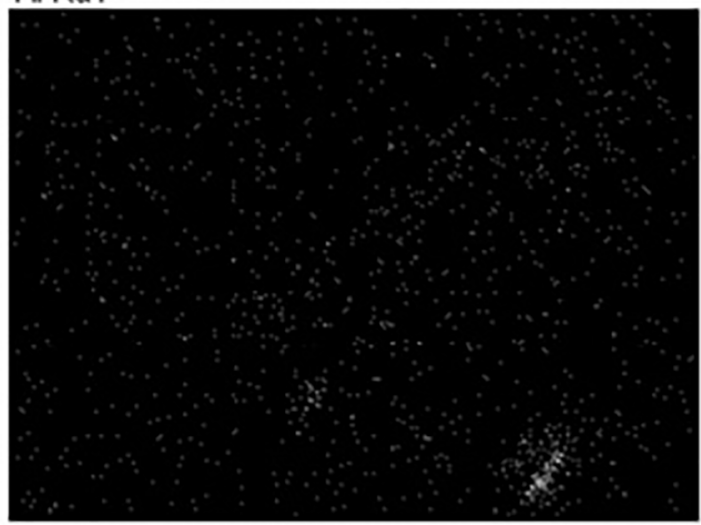

Si Ka1

Figure 10. SEM and EDX mapping on Al 1050 alloy before corrosion tests. The brightness indicates the intensity of the signal of the corresponding element.

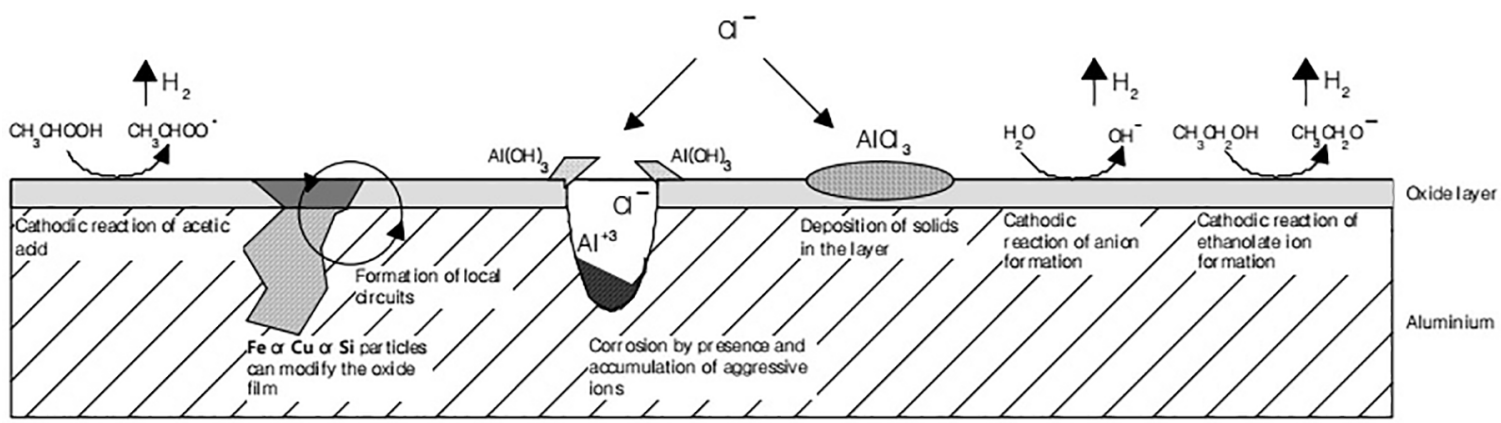

Figure 11. Mechanisms of dissolution of an aluminum alloy exposed to a medium composed of ethanol and contaminants such as aggressive ions, organic acids and water, according to the proposed mechanisms and references cited in the reactions.

through several mechanisms that together form a combined attack on the material.

\section{Conclusions}

The alloys proposed for the management of bioethanol of regional origin (ethanol SJ) were evaluated satisfactorily with an electrochemical method and a gravimetric method, and allowed to obtain the following conclusions:

- Electrochemical tests in reference media (anhydrous ethanol and $96 \%$ ethanol) and in SJ ethanol, at different temperatures, allowed us to understand the action of the contaminants that may exist in bioethanol and its activation with temperature, reflected in the change of the shapes of the potentiodynamic curves and in the change of the electrochemical parameters obtained. Additionally, it was found that the Al1050 alloy showed greater polarization resistance and lower corrosion current than commercial grade aluminum, at $25^{\circ} \mathrm{C}$ and $40^{\circ} \mathrm{C}$ in all proposed media, being similar in behavior for the temperature of $50^{\circ} \mathrm{C}$. 
- The gravimetric tests allowed corroborating the formation of pitting corrosion and the formation of different corrosion products on the pitting. The evaluation of the pitting according to the implemented standard indicates that the obtained values are relatively low (depth of pitting, pitting factor) but still can be the means of propagation of fissures if the material is subjected to determined efforts.

- In comparative form, A11050 alloy presented a better resistance to corrosion up to $40^{\circ} \mathrm{C}$, but its behavior was similar to that of commercial grade aluminum at $50^{\circ} \mathrm{C}$ in $\mathrm{SJ}$ ethanol. However, beyond the economic benefit represented by the use of a more economic alloy, it is necessary to evaluate it subjecting it to specific working conditions.

\section{Acknowledgments}

The authors are grateful to the San Javier sugar mill for their collaboration in the donation of regional bioethanol samples, and FONCyT-ANPCyT for the grant received to finance the present investigation (PICT-2012-2952). G. R. Kramer thanks the CONICET for the scholarship granted to carry out this work.

\section{References}

1. Sorda G, Banse M, Kemfert C. An overview of biofuel policies across the world. Energy Policy. 2010;38(11):6977-6988.

2. Goldemberg J, Coelho ST, Guardabassi P. The sustainability of ethanol production from sugarcane. Energy Policy. 2008;36(6):2086-2097.

3. Farrell AE, Plevin RJ, Turner BT, Jones AD, O'Hare M, Kammen DM. Ethanol can contribute to energy and environmental goals. Science. 2006;311(5760):506-508.

4. Carrizo SC, Velut S, Ramousse D. Biocombustibles en Argentina, Brasil y Colombia: Avances y limitaciones. Geograficando. 2009;5(5):63-82.

5. Del Valle Ríos FL. La producción de bioetanol como un aporte al desarrollo económico de la provincia de Tucumán. [Thesis]. Buenos Aires: Universidad de Belgrano, Escuela de Economía y Negocios Internacionales; 2012.

6. Goldstein E, Gutman GE. Biocombustibles y biotecnología. Contexto internacional, situación en Argentina. Buenos Aires: CEUR-CONICET; 2010.

7. Costa RC, Sodré JR. Hydrous ethanol vs. gasoline-ethanol blend: Engine performance and emissions. Fuel. 2010;89(2):287-293.

8. de Melo TCC, Machado GB, Belchior CRP, Colaço MJ, Barros JEM, de Oliveira EJ, et al. Hydrous ethanol-gasoline blends Combustion and emission investigations on a Flex-Fuel engine. Fuel. 2012;97:796-804.

9. Agarwal AK. Biofuels (alcohols and biodiesel) applications as fuels for internal combustion engines. Progress in Energy and Combustion Science. 2007;33(3):233-271.
10. Cavalcanti E, Wanderley VG, Miranda TRV, Uller L. The effect of water, sulphate and $\mathrm{pH}$ on the corrosion behaviour of carbon steel in ethanolic solutions. Electrochimica Acta. 1987;32(7):935-937.

11. Ambrozim ARP, Kuri SE, Monteiro MR.Corrosão metálica associada ao uso de combustíveis minerais e biocombustíveis. Química Nova. 2009;32(7):1910-1916.

12. Avelar HM, Barbeira PJS. Conductometric determination of total acidity and chloride content in automotive fuel ethanol. Fuel. 2007;86(1-2):299-302.

13. de Anna PL. The effects of water and chloride ions on the electrochemical behavior of iron and 3041 stainless steel in alcohols. Corrosion Science. 1985;25(1):43-53.

14. Galante-Fox J, Von Bacho P, Notaro C, Zizelman J. E-85 Fuel Corrosivity: Effects on Port Fuel Injector Durability Performance. SAE Technical Paper 2007-01-4072; 2007.

15. Jeuland N, Montagne X, Gautrot X. Potentiality of Ethanol as a Fuel for Dedicated Engine. Oil \& Gas Science and Technology. 2004;59(6):559-570.

16. Nie X, Li X, Northwood D. Corrosion Behavior of Metallic Materials in Ethanol-Gasoline Alternative Fuels. Materials Science Forum. 2007; 546-449:1093-1100.

17. Regulatory Services. Underwriters Laboratories. Ethanol fuel dispensing operations in Brazil. Washington: Regulatory Services. Underwriters Laboratories; 2007.

18. Clean Cities, US Department of Energy. Handbook for Handling, Storing, and Dispensing E85 and Other Ethanol-Gasoline Blends. DOE/GO-102016-4854. Washington: US Department of Energy; 2016.

19. Groysman A. Corrosion in Systems for Storage and Transportation of Petroleum Products and Biofuels - Identification, Monitoring and Solutions. Dordrecht: Springer; 2014.

20. Sholz M, Ellerneir J. Korrosionsverhalten unterschiedlicher aluminiumlegierungen in ethanolhaltigem ottokraftstoff unter erhöhten temperaturen. Metaralwissenschaf und Werkstafftechnik, 2006;37(10):842-851.

21. Song GL, Liu M. Corrosion and electrochemical evaluation of an Al-Si-Cu aluminum alloy in ethanol solution. Corrosion Science. 2013;72:73-81.

22. Ministerio Federal de Cooperación Económica y Desarrollo (MFCED). Recomendaciones de especificaciones técnicas para el etanol y sus mezclas (E-6) y la infraestructura para su manejo en México. México: MFCED; 2010.

23. ONU-CEPAL. Especificaciones de la calidad del etanol carburante $y$ del gasohol (mezcla de gasolina y etanol) y normas técnicas para la infraestructura. México: ONU-CEPAL; 2006.

24. Associação Brasileira de Normas Técnicas (ABNT). Norma NBR5992 -Álcool etílico e suas misturas com água - Determinação da massa específica e do teor alcoólico por densímetro de vidro. $2^{\mathrm{a}}$ ed. Associação Brasileira de Normas Técnicas. Rio de Janeiro: ABNT; 2008.

25. Associação Brasileira de Normas Técnicas (ABNT). Norma NBR-9866 - Álcool Etílico-Determinação da acidez total por titulação colorimétrica. $3^{\text {a }}$ ed. Rio de Janeiro: ABNT; 2012. 
26. American Society for Testing and Materials (ASTM). ASTM D-1613-03 - Standard Test Method for Acidity in Volatile Solvents and Chemical Intermediates Used in Paint, Varnish, Lacquer, and Related Products. West Conshohocken: ASTM;2003.

27. Associação Brasileira de Normas Técnicas (ABNT). Norma NBR10547 - Etanol combustível - Determinação da condutividade elétrica. $4^{\mathrm{a}}$ ed. Rio de Janeiro: ABNT; 2016.

28. American Society for Testing and Materials (ASTM). ASTM D-1125-14-Standard Test Methods for Electrical Conductivity and Resistivity of Water. West Conshohocken: ASTM; 2014.

29. American Society for Testing and Materials (ASTM). ASTM G 102 el - Standard Practice for Calculation of Corrosion Rates and Related Information from Electrochemical Measurements. West Conshohocken: ASTM; 2015.

30. Kramer GR, Méndez CM, Ares AE. Corrosion Resistance of Different Aluminum Alloys in Ethanol. In: Williams D, ed. Light Metals. Cham: Springer International Publishing; 2016.

31. American Society for Testing and Materials (ASTM). ASTM G 3172 - Standard Practice for Laboratory Immersion Corrosion Testing of Metals. West Conshohocken: ASTM; 1987.

32. Traldi SM, Costa I, Rossi JL. An electrochemical investigation of the corrosion behavior of $\mathrm{Al}-\mathrm{Si}-\mathrm{Cu}$ hypereutectic alloys in alcoholic environments. Revista de Metalurgía. 2003;39:86-90.

33. Osorio WR, Freire CM, Garcia A. The effect of the dendritic microstructure on the corrosion resistance of $\mathrm{Zn}-\mathrm{Al}$ Alloys. Journal of Alloys and Compounds. 2005;397(1-2):179-191.

34. Lee WJ, Pyun SI. Effects of hydroxide ion addition on anodic dissolution of pure aluminium in chloride ion-containing solution. Electrochimica Acta. 1999;44(23):4041-4049.

35. Totten GE, MacKenzie DS, eds. Handbook of Aluminum: Vol 1: Physical Metallurgy Processes. New York: Marcel Dekker; 2003.
36. Hart RK. The formation of films on aluminum immersed in water. Transactions of Faraday Society. 1957;53:1020-1027.

37. Yoo YH, Park IJ, Kim JG, Kwak DH, Ji WS. Corrosion characteristics of aluminum alloy in bio-ethanol blended gasoline fuel: Part 1. The corrosion properties of aluminum alloy in high temperature fuels. Fuel. 2011;90(3):1208-1214.

38. Park IJ, Yoo YH, Kim JG, Kwak DH, Ji WS. Corrosion characteristics of aluminum alloy in bio-ethanol blended gasoline fuel: Part 2. The effect of dissolved oxygen in the fuel. Fuel. 2011;90(2):633-639.

39. Krüger L, Tuchscheerer F, Mandel M, Müller S, Liebsch S. Corrosion behavior of aluminium alloys in ethanol fuels. Journal of Materials Science. 2012;47(6):2798-2806.

40. Vargel C. Corrosion of Aluminum. Oxford: Elsevier; 2004.

41. Umebayashi R, Akao N, Hara N, Sugimoto K. Corrosion and Its Mechanism of Al- $10 \%$ Si Alloy-Coated Steel in Methanol Containing $\mathrm{H} 2 \mathrm{O}, \mathrm{NaCl}$, and $\mathrm{HCOOH}$. Journal of The Electrochemical Society. 2002;149(3):B75-B83.

42. Pourbaix M. Atlas of Electrochemical Equilibria in Aqueous Solutions. Houston: National Association of Corrosion Engineers; 1974.

43. Thomson JK, Pawel SJ, Wilson DF. Susceptibility of aluminum alloys to corrosion in simulated fuel blends containing ethanol. Fuel. 2013;111:592-597.

44. American Society for Testing and Materials (ASTM). ASTM G 4676 - Standard Practice for Examination and Evaluation of Pitting Corrosion. West Conshohocken: ASTM; 1987.

45. Seri O, Kido Y. Corrosion Phenomenon and its Analysis of 6063 Aluminum Alloy in Ethyl Alcohol. Materials Transactions. 2009;50(6):1433-1439.

46. Davis JR, ed. Corrosion of Aluminum and Aluminum Alloys. Materials Park: ASM International; 1999. DOI: 10.1361/caaa1999p001. 